\title{
ARCHITECT rHTLV-I/II immunoassay for blood screening and diagnosis
}

\author{
Hans-Peter Kapprell, Michael Oer, Boris Heinrich, Carsten Buenning \\ From 15th International Conference on Human Retroviruses: HTLV and Related Viruses \\ Leuven and Gembloux, Belgium. 5-8 June 2011
}

\section{Background}

Detection of HTLV infection continues to be important to control spread of human retroviruses and to protect safety of blood supply. The ARCHITECT rHTLV-I/II assay is a chemiluminescence-based immunoassay, which utilizes HTLV-I, and HTLV-II recombinant antigens and peptides in a double-antigen-sandwich assay format on the Abbott ARCHITECT automated platform. Precision, sensitivity and specificity of the ARCHITECT rHTLV-I/II assay is being presented.

\section{Methods}

Assay performance was evaluated on confirmed HTLVI/II positive specimens and specimens from German Blood Donors and hospitalized patients. External performance evaluation was conducted at two different sites in Portugal. Murex HTLV-I/II EIA was used as comparator assay and INNO-LIA or MP diagnostics HTLV Blot were used for confirmation.

\section{Results}

The ARCHITECT rHTLV-I/II assay detected all HTLVI and HTLV-II specimens $(\mathrm{N}=406)$ in accordance to the Murex assay. Analytical sensitivity was equivalent to Murex based on end-point-dilutions. Specificity on HTLV-I/II blood donors was 99.95\% ( $\mathrm{N}=5646$; 95\% CI 99.84-99.99\%), SD to cut-off was 15.6. Specificity on a diagnostic population was $99.86 \%(\mathrm{~N}=692$; CI $95 \%$ 99.20-100\%). Precision for samples (1-6 S/CO) was 3.98$4.31 \%$. Presented data support selected cut-off multiplier-value of 0.25 for the ARCHITECT rHTLV-I/II assay. Results from the Receiver-Operating-Curve showed a $99.98 \%$ area under the curve which is

* Correspondence: Hans-Peter.Kapprell@abbott.com Abbott GmbH Co KG, Wiesbaden, Germany indicative of high separation power between negative and positive populations.

\section{Conclusions}

This study demonstrated excellent sensitivity and specificity of the ARCHITECT rHTLV-I/II assay. The assay is suitable for both blood screening and diagnosis of HTLV infections and therefore reduces risk of transfusion transmitted HTLV and improves safety of blood supply.

Published: 6 June 2011

doi:10.1186/1742-4690-8-S1-A254

Cite this article as: Kapprell et al:: ARCHITECT rHTLV-I/II immunoassay for blood screening and diagnosis. Retrovirology 2011 8(Suppl 1):A254.

\author{
Submit your next manuscript to BioMed Central \\ and take full advantage of: \\ - Convenient online submission \\ - Thorough peer review \\ - No space constraints or color figure charges \\ - Immediate publication on acceptance \\ - Inclusion in PubMed, CAS, Scopus and Google Scholar \\ - Research which is freely available for redistribution

